\title{
Evaluasi Penanggulangan Tuberkulosis Paru di Puskesmas dalam Penemuan Penderita Tuberkulosis Paru di Kabupaten Sijunjung
}

Deswinda $^{1}$, Rosfita Rasyid ${ }^{2}$, Firdawati ${ }^{3}$

\begin{abstract}
Abstrak
Indonesia merupakan negara nomor dua dengan beban tertinggi akibat Tuberkulosis (TB) di dunia setelah India. Penemuaan penderita TB di Kabupaten Sijunjung dari tahun 2013 sampai 2017 terus mengalami penurunan. Tujuan penelitian ini adalah melakukan evaluasi terhadap penanggulangan TB paru di puskesmas dalam penemuan penderita TB paru dengan pendekatan sistem, yaitu input (kebijakan, sumberdaya manusia, metode, dana, sarana), proses (perencanaan, penggerakkan-pelaksanaan, monitoring dan evaluasi), dan output (pencapaian program penemuan penderita TB) di Kabupaten Sijunjung tahun 2018. Hasil penelitian menunjukkan bahwa kebijakan program TB berpedoman kepada peraturan dari pusat (kementerian kesehatan), tenaga kesehatan dalam penemuan penderita TB kurang, metode yang digunakan dalam penemuan penderita TB adalah pasif dan aktif, dana dan sarana guna penemuan penderita TB masih kurang. Proses, perencanaan di puskesmas sudah sesuai dengan pedoman, penggerakkan-pelaksanaan dalam penemuan penderita TB belum berjalan dengan baik, monitoring dan evaluasi dalam penemuan penderita TB belum berjalan dengan baik. Berdasarkan hasil penelitian dapat disimpulkan bahwa program penanggulangan TB dalam penemuan penderita TB paru di Kabupaten Sijunjung belum berjalan dengan baik dan hasilnya belum mencapai target yang ditetapkan.
\end{abstract}

Kata kunci: evaluasi, program penanggulangan, tuberkulosis, penemuan penderita

\begin{abstract}
Indonesia is the second country that had highest cases with Tuberculosis (TB) in the world after India. Discovery of TB's patients in Sijunjung Regency from 2013 to 2017 continued to be decrease. The objective of this study was to evaluated toward the pulmonary TB's in public health center through the discovery of pulmonary TB patients with a systems approach, including inputs (policies, human resources, methods, funds, facilities), processes (planning, mobilizing-implementation, monitoring and evaluation ), and output (achievement of TB's patient discovery program) in the Sijunjung regency in 2018. The results showed that TB program policies were guided by regulations from the center (ministry of health), health workers in the discovery of TB found lack of patient, the methods that was used in finding TB patients were passive and active, funds and facilities for finding TB patients were still lacking. The planning process in public health center had been appropriate within the guideline of Movement-Implementation in the discovery of TB's patients have not gone well, monitoring and either its evaluation. It could be inferred that the TB's prevention program in the discovery of pulmonary TB's patients in Sijunjung regency had not gone well and the results have not yet reached the set targets.
\end{abstract}

Keywords: evaluation, prevention program, tuberculosis, patients discovery

Affiliasi penulis: 1. Dinas Kesehatan Kabupaten Sijunjung, 2. Bagian IImu Kesehatan Masyarakat. Fakultas Kedokteran Universitas Andalas Padang (FK Unand). 3. Bagian IImu Kesehatan Masyarakat FK Unand
Korespondensi: Deswinda, Email: Deswindabaktiar@gmail.com Telp:08217051482 


\section{PENDAHULUAN}

Salah satu indikator keberhasilan program pengendalian TB paru adalah penemuan kasus (case finding). ${ }^{1}$ Penemuan penderita TB paru BTA positif di Kabupaten Sijunjung dari tahun 2013 sampai tahun 2017 terus mengalami penurunan. Capaian CDR (Case Detection Rate) pada tahun 2013 sebesar 48\%, tahun 2014 adalah 41,60\%, tahun 2015 menjadi $41,10 \%$, tahun 2016 turun kembali menjadi 33,30\% dan tahun 2017 hanya mencapai 30\% dari target nasional $70 \%$ dan target Kabupaten $40 \%{ }^{2} \mathrm{Di}$ Kabupaten Sijunjung, dari 12 puskesmas yang ada, belum satu pun puskesmas yang bisa mencapai target program penemuan TB Nasional (70\%), namun untuk pencapaian target Kabupaten (40\%) baru satu puskesmas yang mencapai target penemuan TB paru meskipun segala upaya telah dilakukan seperti diklat manajemen untuk seluruh pimpinan puskesmas, pelaksanaan sistem ketuk pintu oleh kader TB didampingi tenaga kesehatan, dan pembentukan pos TB nagari. Sedangkan dari 12 puskesmas yang ada tersebut, Puskesmas Kumanis merupakan puskesmas dengan cakupan penemuan penderita TB terendah $(13,3 \%)$ dan Puskesmas Sungai Lansek merupakan puskesmas dengan cakupan penemuan penderita TB tertinggi $(50,8 \%)$ tahun $2017 .^{2}$ Hasil penelitian Yasni (2012) di Kabupaten Sijunjung menunjukkan sebagian besar $(66,7 \%)$ tenaga dalam penemuan TB BTA Positif tingkat puskesmas memiliki pelaksanaan manajemen kurang baik dan tidak memenuhi indikator. ${ }^{3}$ Indikator merupakan alat yang efektif untuk melakukan monitoring dan evaluasi dan menunjukan gambaran keadaan serta dapat digunakan untuk mengukur terjadinya perubahan. Hasil wawancara dan observasi awal di lapangan dengan pengelola program TB paru dan pimpinan puskesmas di 2 puskesmas dengan pencapaian penemuan TB tertinggi dan puskesmas dengan penemuan TB terendah, diperoleh informasi adanya perbedaan pencapaian disebabkan segi input tenaga, yaitu kurangnya komitmen pimpinan dan petugas dalam penemuan penderita TB, dari segi proses pelaksanaan penemuan kasus, terlihat kurangnya kerjasama lintas sektor dengan belum aktifnya Pos TB Nagari yang sudah terbentuk.

Berdasarkan hal tersebut, penulis tertarik melakukan studi mengenai evaluasi penanggulangan tuberkulosis paru di puskesmas dalam penemuan penderita tuberkulosis paru di Kabupaten Sijunjung.

\section{METODE}

Penelitian ini merupakan studi kualitatif dengan tujuan untuk melakukan evaluasi terhadap penanggulangan TB paru di puskesmas dalam penemuan penderita TB paru di Kabupaten Sijunjung yang dilaksanakan di wilayah kerja Puskesmas Sungai Lansek sebagai puskesmas dengan pencapaian penemuan TB paru tertinggi dan Puskesmas Kumanis sebagai puskesmas dengan pencapaian penemuan TB paru terendah. Penelitian ini dilaksanakan mulai Bulan Mei sampai dengan Oktober 2018. Jumlah informan dalam penelitian ini 24 orang yaitu kepala dinas kesehatan, wasor TB, 2 orang pimpinan puskesmas, 2 orang pengelola program TB puskesmas, 2 orang petugas labor puskesmas, 2 orang penanggungjawab upaya kesehatan masyarakat, 2 orang bidan desa, dan 12 orang kader TB di Puskesmas Sungai Lansek dan Puskesmas Kumanis. Teknik pengumpulan data yaitu wawancara mendalam, observasi, telaah dokumen dan focus group discussion.

\section{HASIL}

\section{Komponen Input}

Kebijakan program penanggulangan TB dalam penemuan penderita TB di Kabupaten Sijunjung berasal dari Pemerintah pusat (Kementerian Kesehatan) yaitu berupa Buku Pedoman dan Peraturan Menteri Kesehatan Nomor 6 tahun 2016. Hasil wawancara yang diperoleh dari informan menyatakan kebijakan dalam penemuan penderita TB paru belum terlaksana dengan baik, seperti kerjasama dengan klinik dan praktek swasta baru dibuat di Bulan Desember 2018, penemuan aktif berkala atau tangguak TB akan diaktifkan tahun 2019 dan Pos TB Nagari sebagai pemberdayaan masyarakat untuk penemuan TB belum aktif karena belum ada kegiatan dan masih berupa Surat Keputusan.

Sumber daya manusia (SDM) program penanggulangan TB guna penemuan penderita TB paru, yaitu penanggungjawab TB di Kabupaten (wakil supervisor/wasor TB), pengelola program TB 
puskesmas, analis laboratorium, kepala Puskesmas dan penanggungjawab UKM sebagai manajerial, bidan desa dan kader TB sebagai tenaga pelaksana tingkat bawah dalam penemuan penderita TB. Berdasarkan hasil telaah dokumen, observasi dan wawancara mendalam, diperoleh informasi bahwa tenaga kesehatan dalam penemuan penderita TB paru masih kurang, dan mengerjakan pekerjaan rangkap. Berikut kutipan hasil wawancara dengan pimpinan puskesmas:

"Karena keterbatasan tenaga, kami di puskesmas ini satu petugas memegang beberapa program. Terkadang datang lagi program baru dari nasional, ya..otomatis semua tenaga yang ada diberdayakan untuk kegiatan tersebut sehingga program penemuan pasien TB kurang berjalan...."

Berdasarkan data yang diperoleh di bagian SDM dinas kesehatan, tenaga kesehatan guna penemuan penderita TB paru di Kabupaten Sijunjung masih kurang, antara lain dokter umum kurang 27,6\%, perawat kurang $12,7 \%$, analis kesehatan kurang $30,8 \%$, meskipun pun sudah diupayakan penambahannya dari tenaga kontrak. ${ }^{4}$ Sedangkan dari hasil wawancara dan telaah dokumen, tenaga kesehatan dalam upaya penemuan penderita TB sudah memperoleh pelatihan dan kader TB sudah memperoleh sosialisasi tentang TB, tenaga sudah melibatkan lintas program, lintas sektor seperti kerjasama TB-HIV, TB-DM, serta Pos TB Nagari.

Metode yang dilaksanakan dalam penemuan penderita TB sudah sesuai dengan pedoman yaitu pasif case finding dan aktif case finding, namun belum semua yang ada dibuku pedoman dilaksanakan seperti tidak adanya penjaringan berkala dan skrining massal di kantong-kantong TB, metode penemuan secara pasif lebih banyak dilakukan dari pada aktif karena pengelola program lebih banyak bekerja di pelayanan. Hasil wawancara mendalam dengan pengelola program TB puskesmas diperoleh informasi sebagai berikut:

"Penemuan penderita TB dilakukan saat datang berobat di puskesmas, selain itu penjaringan ke masyarakat seperti pelacakan kasus kontak maupun melalui kegiatan perkesmas. Penjaringan biasanya dilakukan setelah selesai jam pelayanan. Kalau skrining massal di kantong-kantong TB tidak ada dilaksanakan karena sudah bergabung dengan program lain yang melibatkan masyarakat"

Dana/Pembiayaan program TB paru berasal dari dana APBN dan APBD. Dana APBN berupa dana bantuan operasional kesehatan (BOK) yang digunakan di puskesmas untuk penjaringan kasus TB seperti pembiayaan operasional petugas ke lapangan dan pengantaran pot sputum oleh kader TB. Dana APBD digunakan untuk menunjang kegiatan program TB seperti kegiatan pertemuan TB. Hasil wawancara dengan pimpinan puskesmas dan pengelola program TB, dana BOK guna penemuan penderita TB sudah cukup memadai. Hasil wawancara dengan wasor TB di kabupaten, dana APBD kurang memadai disebabkan terbatasnya anggaran pemerintah daerah yang dialokasikan untuk program TB.

Sarana dan prasarana dalam penemuan penderita TB sebagian besar sudah mencukupi, mencakup reagen labor, obat anti tuberkulosis, blanko pencatatan dan pelaporan, pot sputum, buku pedoman, serta media promosi. Namun ada beberapa sarana yang masih kurang dan belum memadai seperti tidak adanya transportasi khusus guna penjaringan TB, tidak adanya ruangan tempat berdahak serta ruangan labor yang belum memenuhi standar. Berikut kutipan hasil wawancara dengan pengelola program TB puskesmas:

"Untuk transportasi guna penjaringan belum ada kendaraan khusus TB, biasanya minjam kendaraan puskesmas yang jumlahnya terbatas atau pakai kendaraan pribadi"

\section{Komponen Proses}

Hasil wawancara, observasi dan dan telaah dokumen tentang perencanaan program TB, perencanaan di dinas kesehatan berdasarkan pagu anggaran yang diberikan. Sedangkan di puskesmas perencanaan sudah dimulai dari analisis masalah, penyebab masalah, pemecahan masalah.

Penggerakkan yang dilakukan dalam penemuan penderita TB di puskesmas Sungai Lansek sudah berjalan dengan cukup baik. Pimpinan puskesmas sudah mengoreksi dan menandatangani pelaksanaan uraian tugas di buku catatan harian setiap hari, pemberian reward untuk pegawai dengan pencapaian target program. Namun di Puskesmas 
Kumanis fungsi penggerakkan belum berjalan baik, dimana catatan pelaksanaan uraian tugas hanya dilihat dan ditandatangani sekali sebulan dan tidak lengkapnya pencatatan lokakarya mini (lokmin) puskesmas. Hasil telaah terhadap notulen pertemuan lokmin, penggerakkan pada saat lokmin di Puskesmas Sungai Lansek dan Puskesmas Kumanis belum sampai kepada rencana tindak lanjut karena keterbatasan waktu. Pelaksanaan penemuan penderita TB di Puskesmas Sungai Lansek dan Kumanis sudah dilakukan dengan cukup baik, seperti telah dilaksanakannya investigasi dan pemeriksaan kasus kontak, namun belum semua kegiatan yang ada di buku pedoman dan peraturan terkait dilaksanakan seperti tidak adanya penjaringan massal di masyarakat. Sebagaimana terdapat dalam Permenkes no. 67 tahun 2016 pasal 11 ayat 2 yang berbunyi:

"Penemuan TB secara aktif dilakukan dengan cara investigasi dan pemeriksaan kasus kontak, skrining secara massal terutama pada kelompok rentan dan kelompok berisiko, dan skrining pada kondisi situasi khusus". 5

Hasil FGD dengan kader TB diperoleh informasi bahwa penemuan penderita TB oleh kader belum terlaksana dengan baik, yang terlihat dari hanya beberapa kader TB yang aktif mengantarkan dahak ke puskesmas. Hasil observasi dan telaah dokumen catatan harian pengelola program TB diperoleh informasi, bahwa pelaksanaan penemuan penderita TB lebih banyak dilakukan di puskesmas dibandingkan turun langsung ke lapangan.

Monitoring dilakukan oleh dinas kesehatan, pimpinan puskesmas dan koordinator UKM. Hasil penelitian mengenai monitoring dan evaluasi, Tidak adanya monitoring dan evaluasi (monev) kepada bidan desa, kader TB dan Pos TB Nagari membuat pemberdayaan penemuan TB tidak berjalan. Monitoring melalui supervisi oleh dinas kesehatan baru bersifat administratif karena dilakukan secara mendadak dan tidak selalu mengisi ceklist supervisi, sedangkan monitoring di puskesmas melalui koordinator UKM belum terlaksana dengan baik karena harus mengerjakan pekerjaan yang ganda, monitoring dan evaluasi melalui lokmin belum sampai kepada rencana tindak lanjut (RTL) karena waktu yang terbatas. Sedangkan, monitoring kepada petugas labor melalui uji silang specimen dahak hanya dilakukan sampai triwulan dua dan tidak semua puskesmas melakukannya.

\section{Output}

Berdasarkan data hasil capaian program penanggulangan TB paru, penemuan penderita TB paru belum mencapai target yang ditetapkan. Sampai Bulan November 2018 rata-rata baru mencapai 20,7\% dari target yang ditetapkan Kabupaten $40 \%$.

\section{PEMBAHASAN}

\section{Masukan}

Kementerian Kesehatan dalam modul kebijakan program penanggulangan TB (2017) menyatakan bahwa kebijakan pengendalian TB di Indonesia dilaksanakan melalui Usaha Kesehatan Masyarakat (UKM) dan Usaha Kesehatan Perorangan (UKP) secara terintegrasi dan kolaborasi dengan program kesehatan lainnya, dengan mengunakan pedoman standar nasional sebagai kerangka dasar dan memperhatikan kebijakan global TB, yang dilaksanakan secara desentralisasi dengan menjamin ketersediaan sumberdaya dalam penanggulangan TB. ${ }^{6}$ Kebijakan penanggulangan TB paru di Kabupaten Sijunjung berpedoman kepada Kementerian Kesehatan sebagai pemerintahan pusat, yang mengacu kepada buku pedoman pengendalian TB tahun 2014, dan Permenkes nomor 67 tahun 2016 yang menjadi pedoman dalam pelaksanaan kegiatan penanggulangan TB. Kebijakan tersebut belum seluruhnya dilaksanakan seperti kerjasama dengan Dokter Praktik Mandiri (DPM) dan Bidan Praktek Mandiri (BPM), klinik dan rumah sakit swasta belum terlaksana, baru berupa pembuatan komitmen untuk pembuatan pencatatan dan pelaporan penemuan TB, yang dilaksanakan pada awal bulan Desember 2018. Hal ini belum sesuai dengan Permenkes no 67 Tahun 2016, dimana di lampiran Permenkes disebutkan bahwa:

"Setiap fasilitas kesehatan yang memberikan pelayanan TB wajib mencatat dan melaporkan kasus TB yang ditemukan dan/atau diobati. Pelanggaran atas kewajiban ini bisa mengakibatkan sanksi administratif sampai pencabutan izin operasional". 5 
Kerjasama dalam hal pelaporan penderita TB di rumah sakit hanya dilakukan dengan Rumah Sakit Sijunjung belum dengan rumah sakit lainnya di sekitar Kabupaten Sijunjung. Seharusnya dengan adanya pelaporan dari rumah sakit disekitar Kabupaten Sijunjung tentang penderita TB akan meningkatkan penemuan penderita TB. Hasil survey riset kesehatan dasar (Riskesdas) tahun 2010 menunjukkan 64\% pasien mengunakan Rumah sakit, BBKPM, dan dokter praktik mandiri untuk berobat. ${ }^{7}$ Hasil evaluasi PPM di berbagai negara yang menunjukkan pendekatan PPM produktif dan costefectif untuk meningkatkan penemuan kasus $10-60 \%{ }^{8}$

Kebijakan lainnya adalah Pos TB Nagari sebagai wadah penemuan penderita TB melalui pemberdayaan masyarakat di tingkat nagari belum berfungsi sebagaimana mestinya, hal ini disebabkan kurangnya monitoring dan evaluasi yang dilakukan puskesmas dan pengelola program terhadap bidan desa, kader TB dan Pos TB Nagari. Hal ini sesuai dengan penelitian Minardo dan Arso (2015) bahwa puskesmas tidak mempunyai rencana implementasi kebijakan TB, sehingga petugas memiliki motivasi yang lemah dalam meningkatkan penemuan penderita TB. ${ }^{9}$

Sumber daya manusia (SDM) yang sesuai dengan standar sangat penting dalam pencapaian tujuan yang telah ditetapkan. sumber daya manusia kesehatan program penanggulangan TB telah sesuai dengan ketentuan yaitu Wasor TB berpendidikan S1 Kesehatan Masyarakat, tenaga pengelola program TB puskesmas pendidikan D III keperawatan, dan tenaga laboratorium berpendidikan DIII Analis. Kendala utama SDM kesehatan dalam penemuan penderita TB adalah pekerjaaan rangkap yang mesti di laksanakan oleh pengelola program TB puskesmas, seperti bertanggungjawab di pelayanan, pemegang program HIV, hepatitis, dan Pembina wilayah yang diberikan oleh pimpinan puskesmas, sehingga pengelola program TB sebagai tenaga inti guna penemuan penderita tidak fokus pada tugasnya. penelitian ini senada dengan penelitian Latifah, Rahayu, dan Indrawati (2018) bahwa tugas rangkap mempengaruhi $(p=0,014)$ kinerja petugas program TB puskesmas. ${ }^{10}$

Tenaga bidan Pustu/Poskesri sebagai tenaga paling bawah dalam penemuan penderita TB mempunyai komitmen yang kurang, hal ini terlihat dari tidak adanya bidan pustu/poskesri yang mencapai target penemuan suspek maupun penderita TB yang diberikan pengelola program, sedangkan bidan pustu/poskesri sangat di butuhkan dalam penemuan penderita TB, karena bidan pustu/poskeri memahami wilayah dan karakteristik penduduk serta pemberi pelayanan kepada masyarakat di wilayah kerjanya.

Pendanaan program penanggulangan TB guna penemuan penderita TB di puskesmas berasal dari Bantuan Operasional Kesehatan (BOK) sudah cukup memadai. sedangkan pendanaan program TB di Dinas Kesehatan Kabupaten Sijunjung masih kurang, hal ini disebabkan karena terbatasnya anggaran dari pemerintah daerah serta pembiayaan program TB bergabung dengan program pencegahan pemberantasan penyakit menular lainnya.

Metode yang dilaksanakan dalam penemuan penderita TB telah sesuai dengan buku pedoman TB yaitu secara pasif dan aktif, namun penemuan penderita TB masih banyak dilakukan dengan menunggu di sarana kesehatan. Penelitian ini senada dengan penelitian Nugraini et al (2015), dimana petugas lebih mengutamakan penemuan secara pasif dibandingkan active case finding. ${ }^{11}$

Sarana dan prasarana dalam penemuan TB masih kurang, yaitu dengan belum adanya ruangan untuk berdahak bagi terduga TB, selama ini terduga TB hanya disuruh mengeluarkan dahak disamping atau depan puskesmas, hal ini bisa menimbulkan rasa risih dan malu bagi terduga TB sehingga mereka malu untuk berdahak dan hanya memberikan air ludah saja. Sarana dan prasarana lainnya seperti obat-obatan, reagen $T B$, formulir pencatatan dan pelaporan dan media promosi sudah mencukupi. Penelitian yang dilakukan oleh Nugraini (2015) menyatakan bahwa tidak adanya tempat berdahak membuat pasien sulit mengeluarkan dahak yang purulen. ${ }^{11}$

\section{Proses}

Perencanaan program penanggulangan TB paru di puskesmas Kabupaten Sijunjung sudah sesuai dengan prosedur yang ditetapkan dalam Permenkes nomor 75 tahun 2014 tentang puskesmas, yang mana perencanaan dimulai dari analisis masalah, penetapan prioritas masalah, mencari penyebab masalah dengan 
diagram Ishikawa dan menetapkan prioritas pemecahan masalah, pembuatan rencana usulan kegiatan (RUK), mengikuti musrenbang dan menyampaikan RUK dalam musrenbang maupun dalam Lokakarya Mini (Lokmin) puskesmas untuk mendapatkan masukan-masukan dari masyarakat dan program lainnya, dan selanjutnya baru pembuatan Rencana Pelaksanaan Kegiatan (RPK). Sudah baiknya dalam pembuatan perencanaan program di puskesmas disebabkan puskesmas sudah akreditasi dan kuatnya dukungan tim akreditasi dinas kesehatan dalam memberikan bimbingan dan pembinaan ke puskesmas dalam pembuatan perencanaan. Hal ini sesuai dengan hasil penelitian Yasni (2012) di Kabupaten Sijunjung, 72,9\% perencanaan TB paru BTA positif tingkat puskesmas dengan kriteria baik. ${ }^{3}$ Sedangkan di Dinas kesehatan pembuatan perencanaan masih belum sesuai dengan ketentuan, dimana pembuatan perencanaan masih berpedoman kepada pagu anggaran yang diberikan.

Penggerakan yang dilakukan oleh Dinas Kesehatan adalah pembagian sasaran program perpuskesmas, belum ada pembagian kelompok kerja baik dalam bentuk lintas program maupun koordinasi lintas sektor dan kemitraan dengan institusi terkait lainnya di tingkat kabupaten (gerakan Terpadu Nasional TB/Gerdunas TB). Penggerakan program TB di puskesmas Sungai Lansek untuk penemuan penderita TB sudah berjalan dengan baik, pimpinan puskesmas dimulai apel pagi sudah mengingatkan staf untuk melaksanakan kegiatan yang harus dilakukan dan diprioritaskan, dan pelaksanaan uraian tugas yang ditandatangani setiap hari sehingga petugas termotivasi untuk melaksanakan uraian tugas, pemberian reward untuk pegawai dengan pencapaian target program. Namun di Puskesmas Kumanis fungsi penggerakan belum berjalan dengan baik, dimana pelaksanaan uraian tugas pada buku catatan harian yang hanya dilihat dan ditandatangani sekali sebulan, belum adanya catatan arahan apel pagi dan catatan Lokmin yang tidak lengkap dan tidak teratur sebagai komunikasi yang baik dan terarah untuk mengerakan bawahan/staf.

Lokmin puskesmas bertujuan untuk menilai seberapa jauh pencapaian program dan apa saja hambatan-hambatan yang ditemui dan pemantauan terhadap RPK yang akan datang sehingga dapat dibuat rencana ulang yang sesuai untuk mencapai tujuan. Namun dari hasil wawancara mendalam lokakarya mini yang dilakukan di Puskesmas waktunya terbatas sehingga tidak semua program bisa dibahas, hal ini sesuai dengan hasil telaah dokumen terhadap notulen pertemuan lokmin puskesmas, yang tidak membahas tentang rencana tindak lanjut terhadap permasalahan yang ada.

Pelaksanaan program TB dalam penemuan penderita TB di Puskesmas Sungai Lansek dan Puskesmas Kumanis sudah dilakukan dengan cukup baik, seperti telah dilaksanakannya investigasi dan pemeriksaan kasus kontak, namun belum semua kegiatan yang ada di buku pedoman dan peraturan terkait dilaksanakan seperti tidak adanya penjaringan massal di masyarakat. Sebagaimana terdapat dalam Permenkes no. 67 tahun 2016 pasal 11 ayat 2 yang menyatakan Penemuan TB secara aktif dilakukan dengan cara investigasi dan pemeriksaan kasus kontak, skrining secara massal terutama pada kelompok rentan dan kelompok berisiko, dan skrining pada kondisi situasi khusus. ${ }^{5}$ Kendala yang ditemukan dalam pelaksanaan penemuan penderita TB antara lain, belum aktifnya Pos TB Nagari yang baru mempunyai surat keputusan tanpa kegiatan tindak lanjut serta kurang aktifnya bidan desa dalam penemuan penderita TB. Oleh karena itu diperlukan monitoring dan evaluasi dengan bidan desa yang disertai reward dan punishment dalam pencapaian target penemuan oleh bidan desa. Sedangkan pelaksanaan penemuan penderita TB oleh kader TB belum terlaksana dengan baik, hanya beberapa kader TB yang aktif mengantarkan dahak ke puskesmas dengan sedikitnya jumlah suspek yang ditemukan. Hal ini disebabkan enggannya masyarakat memberikan dahaknya kepada kader TB. Oleh karena itu perlu bagi puskesmas dan pengelola program TB untuk melakukan pertemuan monitoring dan evaluasi bagi kader TB untuk mengetahui permasalahan dan membuat rencana kegiatan agar kader TB aktif dalam penemuan penderita TB. Penelitian ini berbeda dengan hasil penelitian Yasni (2012) yaitu pelaksanaan penemuan penderita TB paru BTA positif tingkat puskesmas sudah dalam kategori baik $(75.0 \%)^{3}$ 
Monitoring dan evaluasi program TB di puskesmas dilakukan oleh koordinator UKM dan pimpinan puskesmas terhadap ketepatan waktu, ketepatan sasaran dan tempat pelaksanaan Program TB, selain itu untuk menilai apakah pelaksanaan program TB sudah sesuai dengan kerangka acuan, sudah sesuai dengan rencana kegiatan, dan prosedur. Monitoring dan evaluasi di puskesmas dengan cara Kepala puskesmas dan Koordinator UKM mencatat hasil monitoring dari ceklist yang sudah ada, memberitahu kepada pengelola program TB tentang hasil monitoring, Kepala puskesmas dan koordinator UKM bersama dengan pengelola program TB melakukan analisa hasil monitoring, pengelola program TB dan koordinator UKM membuat rencana tindak lanjut berdasarkan hasil analisa monitoring dan evaluasi untuk perbaikan pelaksanaan program TB, selanjutnya evaluasi dilaksanakan pada saat lokmin. Monitoring dan evaluasi penemuan penderita TB kepada bidan desa, kader TB dan Pos TB Nagari belum dilakukan oleh Puskesmas mapun pengelola program. Hal ini terjadi karena kurangnya motivasi yang diberikan oleh wasor TB, dimana pemberian motivasi dan penggerakkan bisa dilaksanakan pada saat supervisi.

Kegiatan monitoring program TB di Dinas Kesehatan masih belum berjalan dengan baik, kegiatan monitoring berupa supervisi program masih bersifat administrasi, dimana supervisi dilakukan dengan tidak selalu mengisi blanko ceklist supervisi, Supervisi terkadang dilaksanakan tanpa adanya perencanaan dan persiapan supervisi seperti pengumpulan informasi pendukungdan pemberitahuan ke puskesmas yang akan disupervisi. Seharusnya supervisi dilaksanakan secara terencana dengan mengkaji laporan ataupun temuan-temuan supervisi sebelumnya seperti temuan yang belum ditindaklanjuti, maupun catatan tentang tindakan perbaikan. Monitoring dan evaluasi di puskesmas yang dilakukan oleh koordinator UKM tidak setiap bulan dilaksanakan, begitu pula dengan blanko ceklist monitoring tidak setiap bulan diisi karena kesibukan koordinator UKM, dimana koordinator UKM selain bertugas di pelayanan, juga bertugas sebagai petugas pengelola program dan koordinator UKM. Kendala pelaksanaan supervisi adalah belum adanya jadwal supervisi, jarang dilakukannya pemecahan masalah yang ditemukan serta belum adanya umpan balik dari supervisor untuk perbaikan. Hal ini senada dengan penelitian Setyowati et al yang menyatakan sebahagian besar $(53,3 \%)$ petugas tidak memperoleh monitoring dan evaluasi yang baik dari pimpinan puskesmas dan dinas kesehatan terkait pelaksanaan P2TB khususnya dalam upaya penemuan penderita TB, kebanyakan supervisi hanya fokus kepada pencatatan dan pelaporan kerja petugas P2TB yaitu $80 \%$ dan $100 \%$. ${ }^{12}$ Penelitian yang dilakukan oleh Yasni (2012) ditemukan bahwa ada hubungan antara monitoring dan evaluasi dengan penemuan penderita TB di Kabupaten Sijunjung. Supervisi yang baik akan meningkatkan kinerja petugas dalam penemuan penderita TB. ${ }^{3}$ Senada dengan penelitian Budi et al (2013), 77\% puskesmas supervisinya kepada bidan pustu, poskesri kurang baik terhadap cakupan penemuan suspek TB. ${ }^{13}$ Diperlukan pengawasan/ supervisi oleh Dinas Kesehatan secara terencana dan bermutu ke Puskesmas, Bidan Pustu/Poskeskel agar penemuan penderita TB di puskesmas

\section{Output}

Laporan yang ada memperlihatkan hasil capaian program Penanggulangan TB paru dalam penemuan penderita TB di Kabupaten Sijunjung sampai Bulan Nonember tahun 2018 tidak mencapai target yang sudah ditetapkan. Capaian penemuan penderita TB di Kabupaten Sijunjung baru mencapai 20,7\% dari target kabupaten $40 \%$ dan target Nasional 70\%. Sedangkan penemuan penderita TB di Puskesmas Sungai Lansek sampai Bulan November 2018 adalah 28\% dan Puskesmas Kumanis 21\%. Hal ini dapat membuktikan bahwa pelaksanaan penemuan penderita TB di Kabupaten Sijunjung belum maksimal, hal ini disebabkan oleh banyak faktor. Salah satunya adalah belum terlaksananya semua kebijakan yang ditetapkan dari pusat seperti belum terlaksananyanya PPM di Kabupaten, Serta monitoring/pengawasan yang belum optimal oleh puskesmas dan Dinas Kesehatan. 


\section{SIMPULAN}

pelaksanaan penanggulangan TB paru di puskesmas dalam penemuan penderita TB paru di Kabupaten Sijunjung belum terlaksana dengan baik, dari segi input, proses dan output. Kebijakan berpedoman kepada pusat yaitu kementerian kesehatan, sumber daya manusia belum mencukupi, metode yang digunakan pasif case finding dan active case finding, dana yang digunakan dari BOK sudah cukup memadai, namun dari APBD masih kurang, sarana dan prasarana dalam penemuan TB masih belum mencukupi secara keseluruhan, perencanaan di puskesmas sudah sesuai dengan pedoman sedangkan di dinas kesehatan perencanaan dibuat berdasarkan pagu anggaran yang diberikan. Penggerakan belum dilaksanakan dengan baik. Pelaksanaan penemuan penderita TB sudah cukup baik namun belum dilaksanakan secara keseluruhan, monitoring dan evaluasi belum berjalan baik. Pencapaian target penemuan penderita TB di Kabupaten Sijunjung belum mencapai target yang ditetapkan.

\section{SARAN}

Dinas kesehatan Kabupaten Sijunjung perlu melakukan pengawasan/supervisi secara terencana dan bermutu ke Puskesmas, Bidan Pustu/Poskeskel dalam penemuan penderita TB. Perlunya menggiatkan kembali skrining massal TB terutama paa kelompok rentan dan beresiko tinggi.

\section{UCAPAN TERIMA KASIH}

Terima kasih dan penghargaan peneliti sampaikan kepada semua pihak yang telah membantu dalam penyelesaian penelitian ini.

\section{DAFTAR PUSTAKA}

1. Kementerian Kesehatan. Tuberkulosis, temukan obati sampai tuntas. Pusat Data dan Informasi Kementerian Kesehatan. Jakarta: Pusdatin. 2015: $1-7$
2. Dinas Kesehatan (Dinkes) Sijunjung. Profil dinas kesehatan kabupaten Sijunjung tahun 2017. Sijunjung: Dinkes; 2017.hlm.155.

3. Yasni. Hubungan manajemen TB paru tingkat puskesmas dengan cakupan penemuan TB paru BTA positif di kabupaten Sijunjung tahun 2012 [skripsi]. Bukittinggi: PSIKM Fort De Kock; 2012.

4. Dinas Kesehatan (Dinkes) Sijunjung. Perencanaan SDMK dinas kesehatan kabupaten Sijunjung tahun 2018. Sijunjung: Dinkes; 2018.hlm.69.

5. Kementerian Kesehatan RI (Kemenkes RI). Peraturan Menteri Kesehatan Nomor 67 Tahun 2016 tentang penanggulangan Tuberkulosis. Jakarta: Kemenkes Rl; 2016.

6. Kementerian Kesehatan RI Direktorat Jenderal Pencegahan dan Pengendalian Penyakit. Modul Pelatihan penanggulangan Tuberkulosis bagi petugas kesehatan. Jakarta: Kemenkes RI; 2017.

7. Badan Penelitian dan Pengembangan Kesehatan RI. Riset kesehatan dasar 2010. Jakarta: Kemenkes RI; 2010.

8. Tondong MAP, Mahendradhata Y, Ahmad RA. Evaluasi implementasi public private mix pengendalian tuberkulosis di kabupaten Ende Provinsi Nusa Tenggara Timur tahun 2012. Jurnal Kebijakan Kesehatan. 2014;03(01):37-42.

9. Minardo J, Arso SP. Analisis determinan motivasi petugas tuberkulosisi paru dalam penemuan kasus di kabupaten Semarang. Jurnal Manajemen Kesehatan Indonesia. 2015;03(01);1-10.

10. Latifah M, Rahayu RS, Indrawati F. Correlated factors on performance of tuberculosis program officers st health center in increasing the finding of new AFB smear-positive case. Unnes Journal of Public Health.2018;7(1):7-13.

11. Nugraini KE, Cahyati WH, Farida E. Evaluasi input capaian case detection rate (CDR) TB paru dalam program penanggulangan penyakit TB paru (P2TB) Puskesmas tahun 2012 (Studi kualitatif di kota Semarang). Unnes Journal of Public Health. 2015; $4(2): 143-52$ 
12. Setyowati I, Saraswatil D, Adi MS. Gambaran faktor-faktor yang terkait dengan kinerja petugas dalam penemuan kasus pada program tuberkulosis paru di kabupaten Grobogan. Jurnal Kesehatan Masyarakat E.jurnal. 2018;6(1):264-73.
13. Budi IS, Darmayanti NA, Wulandari RD. Kontribusi koordinasi terhadap penemuan suspek tuberkulosis paru di kabupaten Mediun. Jurnal Manajemen Kesehatan. 2013;15(1):7-11. 